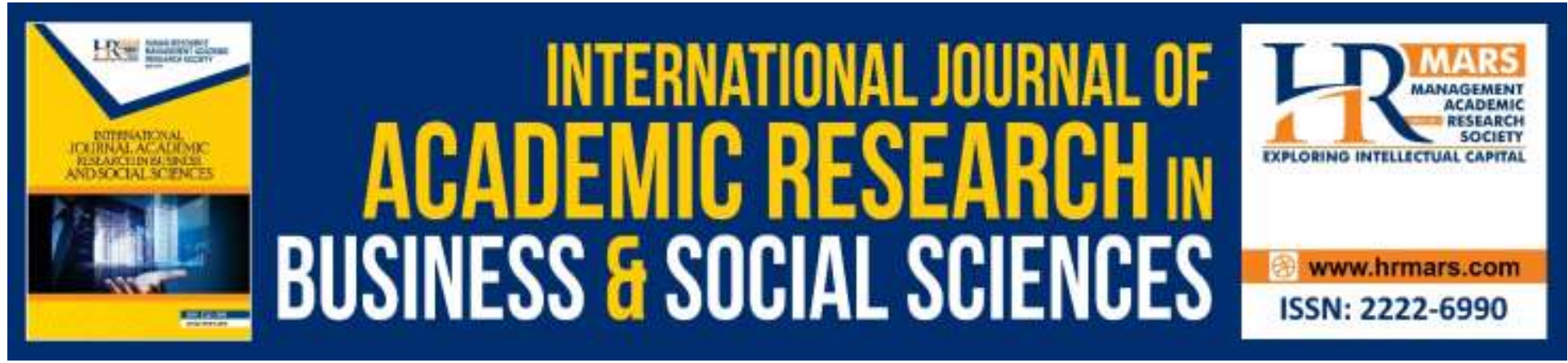

\title{
Conceptualising Personal Resources on Career Adaptability
}

\author{
Khoo Kai Le, Siti Raba'ah Hamzah, Zoharah Omar
}

To Link this Article: http://dx.doi.org/10.6007/IJARBSS/v9-i9/6378

DOI: $10.6007 /$ IJARBSS/v9-i9/6378

Received: 14 August 2019, Revised: 29 August 2019, Accepted: 09 September 2019

Published Online: 29 September 2019

In-Text Citation: (Le, Hamzah, \& Omar, 2019)

To Cite this Article: Le, K. K., Hamzah, S. R., \& Omar, Z. (2019). Conceptualising Personal Resources on Career Adaptability. International Journal of Academic Research in Business and Social Sciences, 9(9), 875-886.

Copyright: (C) 2019 The Author(s)

Published by Human Resource Management Academic Research Society (www.hrmars.com)

This article is published under the Creative Commons Attribution (CC BY 4.0) license. Anyone may reproduce, distribute, translate and create derivative works of this article (for both commercial and non-commercial purposes), subject to full attribution to the original publication and authors. The full terms of this license may be seen

at: http://creativecommons.org/licences/by/4.0/legalcode

Vol. 9, No. 9, 2019, Pg. 875- 886

Full Terms \& Conditions of access and use can be found at http://hrmars.com/index.php/pages/detail/publication-ethics 


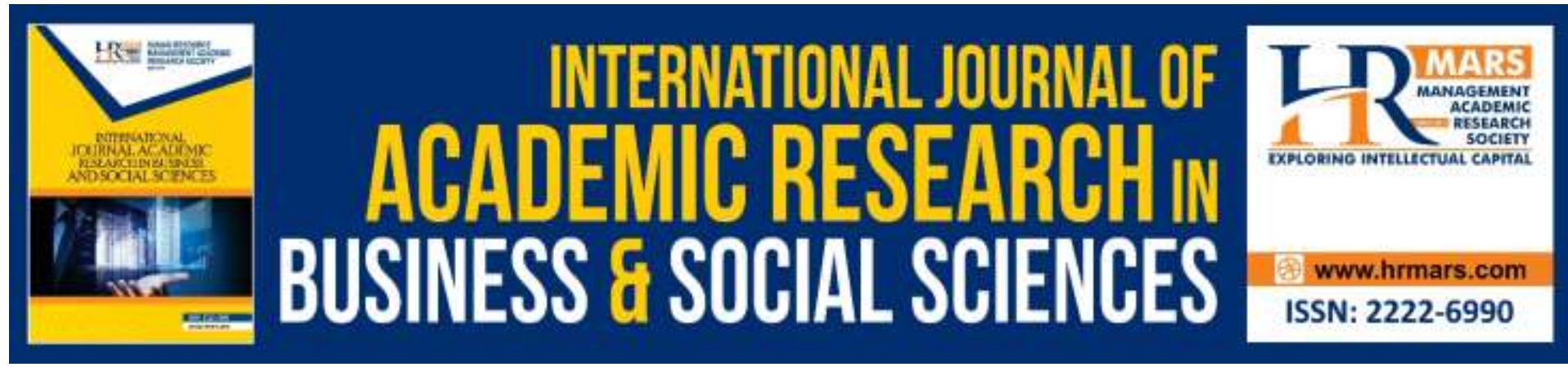

\title{
Conceptualising Personal Resources on Career Adaptability
}

\author{
Khoo Kai Le, Siti Raba'ah Hamzah, Zoharah Omar
}

Department of Professional Development and Continuing Education

Faculty of Educational Studies, Universiti Putra Malaysia, 43400 UPM, Serdang Selangor

\begin{abstract}
The literature on career adaptation is vast and based on a range of different measurement approaches. The present paper aims to understand the influence of personal resources on career adaptability in terms of concern, control, curiosity, and confidence among graduates. This study is based on an extensive review of past research on personal resources and career adaptability using the career construction theory. To conduct the literature review, we used keywords such as personal resources, emotional intelligence, self-esteem, self-efficacy, and career adaptability. From the literature reviewed, three predictors of career adaptability have been identified. They are emotional intelligence, self-esteem, and self-efficacy. The framework offers a number of propositions, which explain the proposed model of career adaptability among the graduates as predicted by personal resources. Further research is suggested to test and validate the framework provide empirical evidence. Upon model validation, the paper could offer stakeholders to assist and develop graduates' personal resources in order to increases their career adaptability and then successful in their career path.
\end{abstract}

\section{Introduction}

In 21st century, by recognising the importance of career and individual career development, people pay more attention on how to shape their career pathway that will lead to a satisfying life. Indeed, individuals construct their subjective career that fits meaning and direction of their lives throughout the life-span (Savickas, 2013) and one of the most important elements in people career path was the career adaptability of an individual. According to Maree (2012), career adaptability has become crucial for individuals who need to direct constant change. Person who are highly adaptable in their vocations have the ability to alter themselves to meet the stressful working world (Autin, Douglass, Duffy, England \& Allan, 2017). People need to adapt to the changes in careers, technology, and various life roles when compared to previous generation (Del Corso, 2013). In order to respond effectively to career transitions, individuals need to display high level emotional intelligence, self-esteem, self-efficacy and career adaptability in their working world. 
As Malaysia aim to achieve an industrialized nation by 2020, there is a need to have workforce that possess a high level of career adaptability in order to ensure the workforce efficiency. This aim can be achieved by having the graduates who are highly intellectual, flexible, having positive attitude in work, self-motivated and willing to learn new skills and technical knowledge. Thus, it is extremely important to identify graduate's state of career adaptability to give appropriate intervention plan and career guidance. However, the unemployment among the graduates has becomes a critical issue in Malaysia. According to annual report cited a study by the Ministry of Education stated that among all graduates in 2015, only 53 percent were reported to have started working within six months of graduating, 18 percent chose to pursue further studies, and 24 percent of them were still unemployed; for the graduates who had started a working, only half of those are able to secure a job (Ibrahim \& Mahyuddin, 2016). The unemployment issue among fresh graduates in Malaysia mainly due to the lack of preparedness and readiness, not career matured enough to cope with the employment issue, do not have suitable skills and qualification to meet the needs of industry, do not show a good working attitudes, and having an unrealistic salaries expectation (Jobstreet, 2015; Zaliza \& Mohd, 2013, Oliver, 2013). Based from resources of job vacancies and job placement in Peninsular Malaysia in 2012, it is revealed that job vacancies are increasing from year to year yet these job vacancies are filled by only a part of the workers. This shows that the unemployment issue is happened not because of the lack of job opportunities but other factors such as the low career adaptability of a graduate in which they are still not ready or compatible to enter the working world at this stage of life cycle. The current level of shortage of required skills and attributes by fresh graduates in the country is alarming, thus drastic measures need to be taken by all stake holders, including the Human Resource Development professionals, career counselors, lecturers, government and the family institution.

There is an abundance of research regarding to the graduate's attitude but there is little research on graduates' readiness in entering the workforce in term of career development view (Kowske, Rasch, \& Wilet, 2010). Therefore, this raises the question: Do fresh graduates have the necessary emotional intelligence, self-esteem, self-efficacy and career adaptability that is needed for the workplace in order to be employed? Some recent studies also investigated the relationships between personal factors and career adaptability (Atac, Dirik, \& Tetik, 2018; Cai et al., 2015 ; Negru-Subtirica, Pop, \& Crocetti, 2015). However, very few of them probed into the realm of the influence of emotional intelligence, self-esteem, and career self-efficacy on career adaptability among graduates in Malaysia. The limited studies available on the correlation between emotional intelligence, self-esteem and career selfefficacy towards career adaptability raise the issues about the relationship between the above mentioned variables.

Consequently, the need for more research to understand the level of career adaptability among the graduates and how the personal resources may affect the graduates' career adaptability was one of the critical concerns to every stakeholder in higher education institution. The present study aimed to add to the extant literature on career development and well-being by how the personal resources such as emotional intelligence, self-esteem, and self-efficacy affect the career adaptability among the graduate. 


\section{Graduates Unemployment Issue: Malaysian Context}

According to Human Resource Minister, over 200,000 graduates were currently unemployed and out of 103,22 of those who have not been able to find employment and 100,390 were those who have quit their employments because of the satisfaction toward the salary as well as found that the job are not suitable for them (Carvalho, Sivanandam, Rahin \& Yunus, 2017). The unemployment trend is apparently more dominant among graduates from Malaysian public universities (Shafie \& Nayan, 2010). According to the Central Bank of Malaysia Annual Report 2016, among the youths in the workforce, the percentage of those unemployed is higher among those with a tertiary education compared to the ones without a tertiary education (Ibrahim \& Mahyuddin, 2016).

These observations invite further questions for academics and policymakers, and more research is warranted to uncover the root causes of these observations, and to design appropriate policy responses (Ibrahim \& Mahyuddin, 2016). The Graduate Employability Blueprint 2012-2017 released by the Ministry of Higher Education stated that graduates are lack of several key characteristics such as strong command of English, the right attitude, and the ability to solve problems (Goon, 2014). All those issue has raised numerous key questions for developing economies such as the quality and relevance of the education system to prepare graduates to enter the rapidly evolving industries and the readiness of the human capital base (Ibrahim \& Mahyuddin, 2016).

In today society, it has been generally accepted that students choose to pursue higher formal education with the expectation that the higher education would increase their readiness to attain a job and salary in the future employment. However, excellent academic performance may not guarantee the employment of the students because grades are often serve as only one of the criteria set by the employers in recruitment process. Students with only good academic performance are no longer guarantee for the employment once they graduate. The success in the job market would depend greatly on graduates' adaptability in which they must be able to face and adapt with the fierce working environment.

\section{Definition of Career Adaptability}

Career adaptability is a psychosocial construct that involves a combination of attitudes, competencies, and behaviors that individuals use in fitting themselves to work (Saviskas, 2013). It indicates the resources that individuals need to successfully manage current and unexpected career transitions (Savickas, 2005). These resources serve as self-regulation strategies that enable individual to expand, polish and implement their self-concepts in career roles (Savickas, 2005). Rossier et al. (2012) define career adaptability as the individual's readiness to respond to change and the coping resources which enable them to cope with the work change. Thus, career adaptability contributes to develop and determine the strategies of an individual for managing their career tasks and challenges.

According to Hirschi (2009), career adaptability is an aggregate construct and not a dormant construct, in which it is formed by a combination of its single measure indicators and dimensions that indicate the unique and shared variance of the measures. The four dimensions are concern, control, curiosity and confidence (Saviskas \& Porfeli, 2012). Career concern helps an individual to look ahead and prepare for their future and developing a sense of hopefulness attitude about future; Career control enables an individual to take control over one's future which being more responsible in making career related decision; Career curiosity comprises exploring one's opportunities and thinking about the fit between self and different 
environments, career roles, and future scenarios; Career confidence refers to people's perceived ability to solve problems and to overcome obstacles in order to pursue their career aspiration (Hartung \& Michael, 2017).

Therefore, an adaptive individual is conceptualised as (a) becoming concerned about the vocational future, (b) increasing personal control over one's vocational future, (c) displaying curiosity by exploring possible selves and future scenarios, and (d) strengthening the confidence to pursue one's aspirations (Savickas \& Porfeli, 2012). Thus, when adaptable individuals facing the change, they will be more concerned about their future, take control to prepare it, discover the substitutions through their curiosity and follow their aspirations through establish confidence (Savickas \& Porfeli, 2012).These dimensions of career adaptability enable individual to change their behaviours to suit for the changing and demands that needed from the work environment. Thus, the personal resource which enables coping with the changing work environment is seen as the importance factor in graduate's career adaptability.

\section{Career Construction Theory}

Career construction theory (CCT) by Saviskas (2005) provides a way of thinking about how individuals choose and practice work as well as presents an ideal for comprehending career behaviour across the life-cycle and to maintain successful and satisfying work lives. It driven by adaptation to the social environment and the ultimate goal is to integrate into the environment. CCT focus on the adaptation of individuals within the organisation, the manner in which individuals prepare to enter and participate in their work role, and the way that individuals deal with career transition and career changes. CCT emphasises individuals are active agents in building their career by imposing the meaning on career behaviour (Watson \& McMahon, 2009). Thus, an occupation is recognised as a way for an individual to sustain themselves in the society through social integration. CCT incorporates and updates previous theoretical contributions and frameworks (Super, 1957, 1990; Holland, 1997) concepts and presents three majors components: Vocational personality (an individual's career-related abilities, needs, values, and interests), life themes (an individual's build their careers by imposing meaning on vocational behaviour) and career adaptability (how an individual constructs a career) (Savickas, 2005).

In CCT, the word adapt refers to change or fit in. According to Saviskas and Porfeli (2012), the word adapt has been used in various ways to denote a sequence ranging from adaptive readiness, adaptability resources, adapting responses and adaptation outcome. This refer to all individuals were need to prepared to change (adaptive readiness), possess differing resources to assist in managing the change (adaptability resources) and will proceed to change when it is required (adapting responses), which later result them for a more integrated into their life roles (adaptation outcome) (Saviskas \& Porfeli, 2012). As the work environment change, people adapt it to retain their personal work environment fit.

Career construction theory attempts to implement a self-concept in social roles which focuses on the adaptation to a series of transitions from school to work and from job to job. This transition is promoted by five principal types of behaviours: orientation, exploration, establishment, management, and disengagement and this constructive behaviours form a cycle of adaptation that is periodically repeated as new transitions appear (Saviskas \& Porfeli, 2012). As each transition approaches, people can adapt more effectively if they meet the 
change such as growing awareness, information-seeking, informed decision making, temporary behaviours (Saviskas, 2005; Matarid, Sobh, \& Ahmed, 2018).

Far from year 2005, Saviskas had claims that people now a day do not work at one job only for thirty years. They change jobs frequently and go through numerous transitions and repeating the cycle of orientation, exploration, stabilization, management, and disengagement (Hartung, 2013). One's ability to adapt the new circumstances is improved by certain coping resources for solving the unfamiliar, difficult, and unclear problems presented by developmental tasks, occupational transitions, and work traumas (Saviskas, 2005). CCT highlights a set of specific attitudes, beliefs and competencies (refer as career construction $A B C^{\prime} s$ ) shape the actual problem solving strategies and managing behaviours that individuals use to make up their career self-concepts with work roles (Saviskas, 2005). The ABCs later are grouped into four dimensions of adaptability which are concern, control, curiosity, and confidence.

Career construction theory attempts to implement a self-concept in social roles which focuses on the adaptation to a series of transitions from school to work, it is appears as the core theory in explaining the relationship between personal resources (emotional intelligence, self-esteem and self-efficacy) and career adaptability among the graduates.

\section{Personal Resources}

Personal resources are the resiliency and adaptability that employees need to successfully handle any given situation. According to Xanthopoulou, Bakker, Demerouti, and Schaufeli (2009), personal resources support the achievement of organizational goals, growth, and improvement. Personal resources refer to those personal characteristics that promote a person's sense of control and self-evaluation as well as the ability to control one's environment in a successful way (Hobfoll, Johnson, Ennis, \& Jackson, 2003). It acts as proximal predictors of career adaptability, which helps an individual to fitting themselves in working environment. Graduates with high level of personal resources invest their energy in broadening their experience and exceeding the expectations of their job.

In this research, emotional intelligence, self-esteem, and self-efficacy will be served as primary personal resources that will affect the level of career adaptability among the graduates.

\section{Emotional Intelligence}

Emotional intelligence is defined as individual ability to perceive, understand and express emotions (Mayer \& Salovey, 1997). Bar-On (2010) defines emotional intelligence as a range of non-cognitive capabilities, competencies, and skills that influence an individual ability to succeed in coping with an environmental demands and stresses. Numerous definitions of emotional intelligence all share similar theoretical foundations, which include an awareness of one's own emotions, an awareness of emotions in others, and the ability to manage one's own emotions and the emotions of others. Thus, emotional intelligence refers to the level of abilities for an individual to understand own feelings and others, managing own emotion well and in their relationship.

According to Marzuki, Mustaffa and Saad (2015), general intelligence (IQ) alone cannot guarantee individual success in life; psychologists report that only $20 \%$ of individual success 
in life is as a result of $I Q$, while the remaining $80 \%$ is due to other factors such as emotional intelligence. Research conducted by Coetzee and Harry (2014) has highlighted the importance of developing individuals' emotional intelligence in order to strengthen employees' career adaptability. Thus, study expect that the emotional intelligence is positive predict career adaptability in which both variables are self-regulatory strategies that serve as important psychosocial resources in person and environment interaction (Savickas \& Porfeli, 2012). Emotional intelligence and career adaptability are thought to be more flexible cognitiveaffective behavioural underlying characteristics and abilities that can be improved through training, counselling, and coaching (Johnston et al., 2013; Di Fabio et al., 2012; Savickas \& Porfeli, 2012,). Research that examines the relationship between emotional intelligence and career adaptability is therefore considered important to design the interventions that help individuals successfully manage their career development.

$\mathrm{H} 1$ : There is a positive relationship between emotional intelligence and career adaptability among graduates.

\section{Self-Esteem}

Self-esteem refers to one's positive or negative perceptions towards themselves by considering the views of others around him/her (Atac, Dirik, Tetik, 2018). According to Huysse-Gaytandjieva, Groot, Pavlova, and Joling (2015), self-esteem is an integral part of the self-concept which is highly connected with career and employment opportunities and it is found to be a predictor of future unemployment. Individual with high self-esteem tend to see themselves as capable and worthy, while individual with low self-esteem often doubt their own abilities and suspicious about their self-worth. Thus, graduates with strong positive beliefs about themselves will be more likely to feel easy to face the challenges and adapt to the required change. In this study, self-esteem was operational as the level of self-worth and personal value among graduates.

Research conducted by Vianen, Klehe, Koen, and Dries (2012) and Duffy (2010) in Netherland and United State had found that there is a positive correlation between self-esteem and adaptability. In Rossier, Zecca, Stauffer, Maggiori, and Dauvalder (2012) study also found that there is a significantly negative correlation between career adaptability and low self-esteem. Thus, it can be predict that the graduates self-esteem is positive related to their career adaptability.

$\mathrm{H} 2$ : There is the positive relationship between self-esteem and career adaptability among graduates.

\section{Career Self-Efficacy}

Bandura (1977) defined self-efficacy as a person's beliefs in one's ability to successfully perform a given task or behaviour. Bandura believed that self-efficacy beliefs influence the course of action people choose to pursue; how much effort they will expend; how long they will keep it up when faced with obstacles and failures; and how much they will eventually accomplish. Individual with high efficacy beliefs are very optimistic and with the positive belief, he or she will be more easily to adapt with the challenges that are hinder from the external environment.

According to Wan et al. (2011), career self-efficacy is developed and increasingly expressed via four major processes and sources of information. These sources include a) past 
performance undertakings and successful mastery experience, b) indirect learning experiences through observing the others performance, c) verbal persuasion (social influences), and d) emotional arousal (anxiety and other negative emotional) (Wan et al., 2011). These self-efficacy sources are important to the understanding of career adaptability among the graduates in which it characteristics variable can help an individual to adjust, adapt and respond to the career development situation. Later, researchers have focused their efforts on investigating the role self-efficacy plays in the process of career decision-making. (Sangakala, Ahmed, \& Pahi, 2016).

Finning and May (2013) conduct a studies among the college students and found that the higher the level of self-efficacy can help individuals to get more information in choosing the career choice. Gadassi et al. (2013) study on adaptability of career decision-making profiles of pre-freshman undergraduate students had found that students with higher career aspirations mediated by decision making self-efficacy are likely to have higher career adaptability. Self-efficacy enables the students to have a better preparation for their future career. Therefore, students with high career self-efficacy will let to higher level of career adaptability and then bring the students to be more likely to believe that they will be success in their career.

H3: There is a positive relationship between self-efficacy and career adaptability among graduates.

\section{Conceptual Framework}

Based on the above discussion, study developed a conceptual framework as depicted in Figure 1

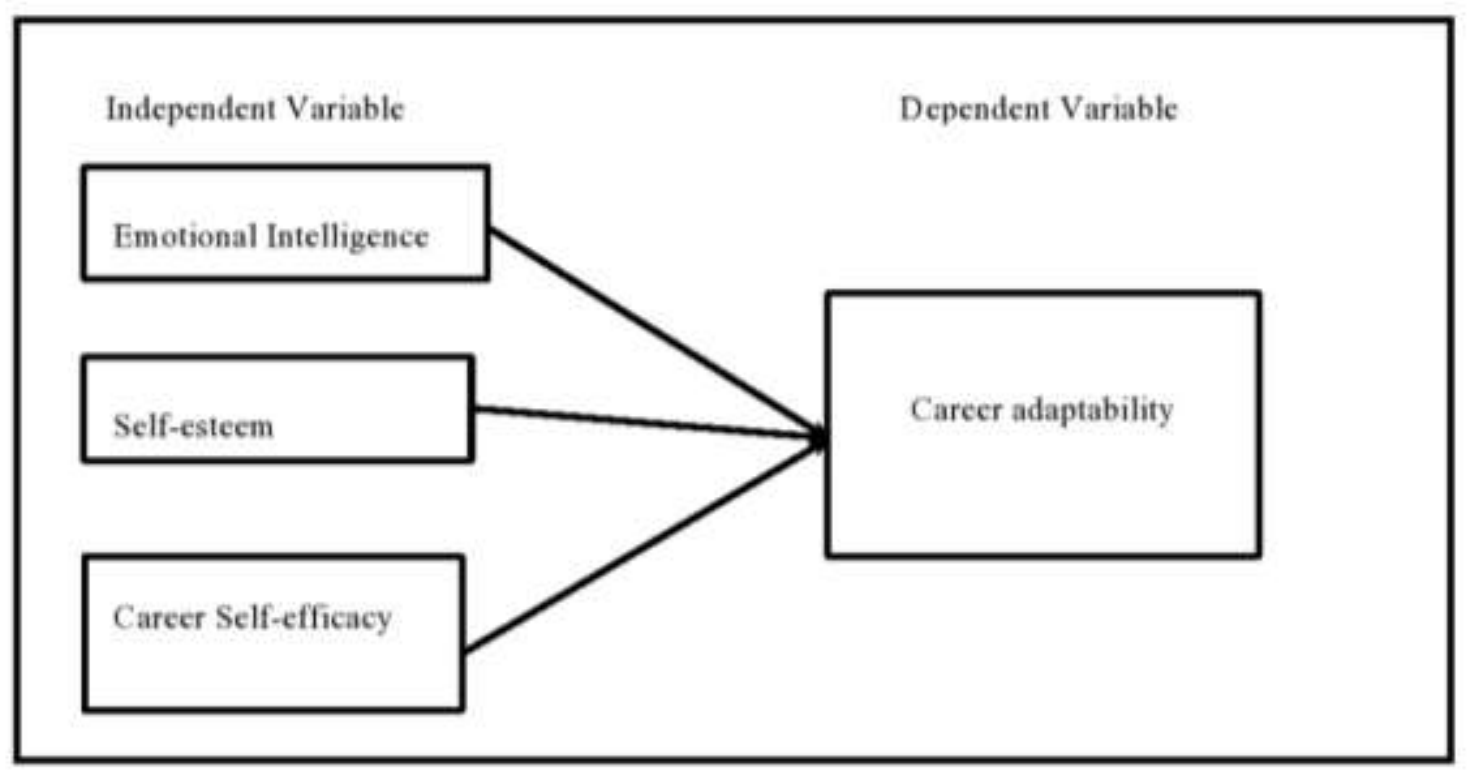

Figure 1: A framework showing the predictors of career adaptability based on personal resources.

\section{Conclusion and Implication}

Career adaptability has recently emerged as a significant topic of inquiry and a source of bargaining power in the increasingly complex and rapidly changing labour market that 
requires equally adaptable actors. Career adaptability is an important psychosocial resource for graduates in facing the unpredictable, diverse, and global careers for their future careers. The relevant literature evidenced that personal resources (such as emotional intelligence, self-esteem, and self-efficacy) present as the factors determining the degree to which career adaptability becomes relevant and is enhanced. This paper provides a theoretical support and develops a research model that investigates the relationship between personal resources (emotional intelligence, self-esteem and self-efficacy) and career adaptability among the graduates.

This study contributes to the body of knowledge of career development in human resources development by clarifying the personal resources factors that influence career adaptability among the university students from a non- western country. As career development happens when individuals adapt to the change in order to respond to vocational development task and world of work changes as well as manage career transition throughout the life. Career construction theory also suggests the mutual relations between individuals' career competences (career adaptability and career behaviours (e.g., career exploration), as career development consists of the continuous cycles of growth (orientation), exploration, engagement, management and disengagement (Savickas, 2005; Savickas \& Porfeli, 2012).

In additional, this study also provided the career development knowledge for HRD professionals, career counsellors, lecturers, government and family institution to provide additional support to those fresh graduates who are likely to experience no or even negative change in career adaptability in order to guarantee the graduates are able to complete schoolwork transition successfully.

Lastly, this study seeks to create the awareness among the graduates on the need for personal resources such as emotional intelligence, self-esteem and self-efficacy in improving their level of career adaptability. Graduates are able to find out what kind of personal resources will affect their career adaptability in order to acquire with the most suitable skills, knowledge and attitude that they should possess in order to be employed and success in their career development.

Future research is recommended to empirically test and validate the propositions on the links between personal resources and career adaptability. Consequently, empirical evidence that could be obtained based on this model may contribute to the emerging literature on the role of personal resources in emotional intelligence, self-esteem and self-efficacy leading to career adaptability among the fresh graduates. In theoretically, this research is valuable for researchers to understand career development process among university students in Malaysia as a multi-cultural eastern country.

\section{Corresponding Author}

Siti Raba'ah Hamzah

Department of Professional Development and Continuing Education

Faculty of Educational Studies

Universiti Putra Malaysia, UPM, 43400 Serdang, Selangor, Malaysia

Email: srh@upm.edu.my 


\section{References}

Atac, L. O., Dirik, D., \& Tetik, H. T. (2018). Predicting Career Adaptability through Self-Esteem and Social Support: A Research on Young Adults. International Journal for Educational and Vocational Guidance, 18 (1), 45-61. doi.org/10.1007/s10775-017-9346-1.

Autin, K. A., Douglass, R. P., Duffy, R. D., England, J. W., \& Allan, B. A. (2017). Subjective social status, work volition, and career adaptability: A longitudinal study. Journal of Vocational Behavior, 99, 1-10. doi.org/10.1016/j.jvb.2016.11.007.

Bandura, A. (1977). Social learning theory. Englewood Cliffs, NJ: Prentice Hall.

Bar-On, R. (2010). Emotional intelligence: an integral part of positive psychology. South African Journal of Psychology, 40(1), 54-62. doi.org/10.1177/008124631004000106.

Cai, Z., Guan, Y., Li, H., Shi, W., Guo, K., Liu, Y., \& Hua, H. (2015). Self-esteem and proactive personality as predictors of future work self and career adaptability: An examination of mediating and moderating processes. Journal of Vocational Behavior, 86, 86-94. doi.org/10.1016/j.jvb.2014.10.004.

Carvalho, M., Sivanandam, H., Rahim, R., \& Yunus, A. (2017). 500,000 currently jobless. The Star Online. Retrieved from https://www.thestar.com.my/news/nation/2017/03/23/500000-currently-joblessriot-number-considered-low-going-by-international-benchmarks/

Coetzee, M. \& Harry, N. (2014). Emotional intelligence as a predictor of employees' career adaptability. Journal of Vocational Behavior, 84(1), 90-97. doi.org/10.1016/j.jvb.2013.09.001.

Guzman, D. A., \& Choi, K. O. (2013). The relations of employability skills to career adaptability among technical school students. Journal of Vocational Behavior, 82, 199-207. doi.org/10.1016/j.jvb.2013.01.009.

Corso, D. J. (2013). The theory of career adaptability. In A. di Fabio \& J. G. Maree (Eds.), The psychology of career counseling: New challenges for a new era (pp. 117-130). New York, NY: Nova Science Publishers, Inc

Fabio, D. A., Palazzeschi, L., \& Bar-On, R. (2012). The role of personality traits, core selfevaluation, and emotional intelligence in career decision-making difficulties. Journal of Employment Counseling, 4, 118-129. doi.org/10.1002/j.2161-1920.2012.00012.x.

Duffy, R. D. (2010). Sense of Control and Career Adaptability among Undergraduate Students. Journal of Career Assessment, 18(4), 420-430. doi.org/10.1177/1069072710374587.

Gadassi, R., Gati, I., \& Wagman-Rolnick, H. (2013). The adaptability of career decision making profiles: Associations with self-efficacy, emotional difficulties, and decision status. Journal of Career Development, 40(6), 490-507. doi.org/10.1177/0894845312470027.

Goon, J. (2014). Three E's to employability. The Star Online. Retrieved from http:// www.thestar.com.my/News?education/2014/01/26/Three-E's-to-employability/.

Hanapi, Z., \& Nordin, M. S., (2013). Unemployment among Malaysia graduates: graduates' attributes lecturers' competency and quality of education. Social and Behavioral Sciences, 112, $1056-1063$. doi.org/10.1016/j.sbspro.2014.01.1269. 
Hartung, P. J. (2013). Career construction counseling. In A. di Fabio \& J.G. Maree (Eds.), The psychology of career counseling: New challenges for a new era (pp.15-28). New York, NY: Nova Science Publishers, Inc.

Hartung, P. J., \& Michael, C. C. (2017). Career Adaptability: Changing Self and Situation for Satisfaction and Success. In K. Maree (ed.), Psychology of Career Adaptability, Employability and Resilience (pp. 15-28). Springfield, MA: Springer International Publishing AG 2017.

Hirschi, A. (2009). Career adaptability development in adolescence: Multiple predictors and effect on sense of power and life satisfaction. Journal of Vocational Behavior, 74, 145155. doi.org/10.1016/j.jvb.2009.01.002.

Hobfoll, S. E., Johnson, R. J., Ennis, N., \& Jackson, A. P. (2003). Resource loss, resource gain, and emotional outcomes among inner city women. Journal of Personality and Social Psychology, 84, 632-643. doi.org/10.1037/0022-3514.84.3.632.

Huysse-Gaytandjieva, A., Groot, W., Pavlova, M., \& Joling, C. (2015). Low self-esteem predicts future unemployment. Journal of Applied Economics, 18(2), 325-346. doi.org/10.1016/S1514-0326(15)30014-3.

Ibrahim, D. \& Mahyuddin, M. (2016). Youth Unemployment in Malaysia: Developments and Policy Considerations. Annual Report 2016. Retrieved from https://www.bnm.gov.my/files/publication/ar/en/2016/cp04_003_box.pdf

JobStreet.com (2015). Retrieved from https://www.jobstreet.com.my/careerresources/employers-fresh-graduatesunrealistic-expectations/\#.WR25K9J97IV

Johnston C. S., Luciano E.C., Maggiori, C., Ruch, W., \& Rossier, J. (2013). Validation of the German version of the Career Adapt-Abilities Scale and its relation to orientations to happiness and work stress. Journal of Vocational Behavior, 83, 295-304. doi.org/10.1016/j.jvb.2013.06.002.

Kowske, B. J., Rasch, R., \& Wiley, J. (2010). Millennials'(lack of) attitude problem: An empirical examination of generational effects on work attitudes. Journal of Business and Psychology, 25(2), 265-279.

Maggiori, C., Johnston, C. S., Krings, F., Massoudi, K., \& Rossier, J. (2013). The role of career adaptability and work conditions on general and professional wellbeing. Journal of Vocational Behavior, 83(3), 437-449. doi.org/10.1016/j.jvb.2013.07.001.

Maree, J. B. (2012). Career Adapt-abilities Scale - South African form: Psychometric properties and construct validity. Journal of Vocational Behaviour, 80,730-733. doi.org/10.1016/j.jvb.2012.01.005.

Marzuki, N. A., Mustaffa, C. S., \& Saad, Z. M. (2015). Emotional Intelligence : It's Relationship with Communication and Information Technology Skills. Asian Social Science, 11(15), 267-274. doi.org/10.5539/ass.v11n15p267.

Matarid, N. M., Sobh, O. S., \& Ahmed, U. (2018). The Impact of Organizational Justice and Demographics on Faculty Retention in Bahrain. Le travail humain, (3).

Mayer, J. D., \& Salovey, P. (1997). What is emotional intelligence? In P. Salovey \& D. Sluyter (Eds.), Emotional development and emotional intelligence: Educational implications (pp. 3-31). New York, NY: Basic Books.

Negru-Subtirica, O., Pop, E. I., \& Crocetti, E. (2015). Developmental trajectories and reciprocal associations between career adaptability and vocational identity: A three wave 
longitudinal study with adolescents. Journal of Vocational Behaviour, 88, 131- 142. doi.org/10.1016/j.jvb.2015.03.004.

Oliver, B. (2013). Graduate attributes as a focus for institution-wide curriculum renewal: innovations and challenges. Higher Education Research and Development, 32(3), 450463. doi.org/10.1080/07294360.2012.682052.

Rossier, J., Zecca, G., Stauffer, S. D., Maggiori, C., \& Dauvalder, J. P. (2012). Career adaptabilities scale in a French-speaking Swiss sample: Psychometric properties and relationships to personality and work engagement. Journal of Vocational Behavior, 80, 734-743. doi.org/10.1016/j.jvb.2012.01.004.

Sangakala, M., Ahmed, U., \& Pahi, M. H. (2016). Empirical investigating on the role of supervisor support, job clarity, employee training and performance appraisal in addressing job satisfaction of nurses. International Business Management, 10(23), 5481-5486.

Savickas, M. L. (2005). The Theory and Practice of Career Construction. In S. D. Brown \& R. W. Lent (Eds.), Career development and counseling: Putting theory and research to work (pp. 42-70). Hoboken, NJ, US: John Wiley \& Sons Inc.

Savickas, M., \& Porfeli, E. (2012). Career Adapt-Abilities Scale: Construction, reliability, and measurement equivalence across 13 countries. Journal of Vocational Behavior, 80(3), 661-673. doi.org/10.1016/j.jvb.2012.01.011.

Savickas, M. L. (2013). Career construction theory and practice. In R. W. Lent, \& S. D. Brown (Eds.), Career development and counselling: Putting theory and research into work (pp. 147-183) (2nd ed.). Hoboken, NJ: Wiley.

Shafie, L. A., \& Nayan. (2010). Employability awareness among Malaysian undergraduates. International Journal of Business Management, 5(8), 199-123. doi.org/10.5539/ijbm.v5n8p119.

Teixeira, M. A. P., Bardagi, M. P., Lassance, M. C. P., Magalhães, M. O., \& Duarte, M. E. (2012). Career Adapt-Abilities Scale-Brazilian Form: Psychometric properties and relationships to personality. Journal of Vocational Behavior, 80(3), 680-685. doi.org/10.1016/j.jvb.2012.01.007.

Vianen, V. A. E. M., Klehe, U. C., Koen, J., \& Dries, N. (2012) Career adapt-abilities scale Netherlands form: psychometric properties and relationships to ability, personality, and regulatory focus. Journal of Vocational Behavior, 80(3), 716-724. doi.org/10.1016/j.jvb.2012.01.002.

Wan, M. W. J., Mohamed, O., Bakar, A. R., \& Tarmizi, R. A. (2011). Counseling self-efficacy among trainee counselor in Malaysia. Social and Behavioral Sciences, 30, 676-679. doi.org/10.1016/j.sbspro.2011.10.130.

Watson, M., \& McMahon, M. (2009). Career counseling in South African higher education: Moving forward systemically and qualitatively. South African Journal of Higher Education, 23(3), 470-481. doi.org/10.4314/sajhe.v23i3.51026.

Xanthopoulou, D., Bakker, A. B., Demerouti, E. \& Schaufeli, W. B. (2009). The Role of Personal Resources in the Job Demands-Resources Model. International Journal of Stress Management, 14(2), 121-141.

doi.org/10.3389/fpsyg.2016.01214. 